Simulation of the Intraseasonal Variability Over the Eastern Pacific ITCZ in Climate Models

K. R. Sperber

June 1, 2011 
This document was prepared as an account of work sponsored by an agency of the United States government. Neither the United States government nor Lawrence Livermore National Security, LLC, nor any of their employees makes any warranty, expressed or implied, or assumes any legal liability or responsibility for the accuracy, completeness, or usefulness of any information, apparatus, product, or process disclosed, or represents that its use would not infringe privately owned rights. Reference herein to any specific commercial product, process, or service by trade name, trademark, manufacturer, or otherwise does not necessarily constitute or imply its endorsement, recommendation, or favoring by the United States government or Lawrence Livermore National Security, LLC. The views and opinions of authors expressed herein do not necessarily state or reflect those of the United States government or Lawrence Livermore National Security, LLC, and shall not be used for advertising or product endorsement purposes.

This work performed under the auspices of the U.S. Department of Energy by Lawrence Livermore National Laboratory under Contract DE-AC52-07NA27344. 


\section{Simulation of the intraseasonal variability over the Eastern Pacific ITCZ in climate models}

\section{Objectives}

- Evaluate boreal summer intraseasonal and quasi-biweekly rainfall variability over the tropical East Pacific in climate models

- Investigate model physics to determine configurations favorable for the simulation of these modes of variability

\section{Approach}

- Analyze 6 atmospheric models and 3 coupled models

- Use extended EOF analysis to evaluate how well the models simulate the two leading modes of $10-90$ variability

- Evaluate the life-cycle and propagation characteristics

\section{Examples of eastward propagation}
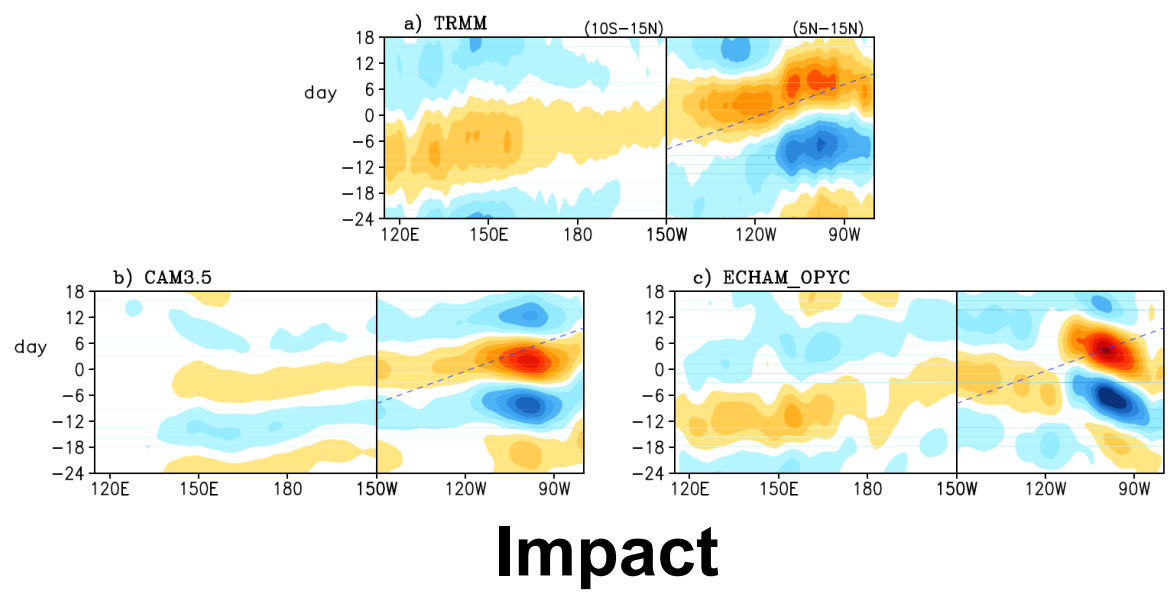

- Four models simulate the eastward and northward propagation of the intraseasonal mode, but the period is too fast

- Convective parameterization that permits the build-up of sufficient tropospheric moisture yields improved simulation of these modes of variability

- High horizontal resolution appears to be favorable for simulating the quasibiweekly mode 